\title{
鋼管杭の極限支持力推定法に関する研究
}

\section{STUDY ON METHODS FOR EVALUATION OF BEARING CAPACITY OF STEEL PIPE PILES}

\author{
松尾 稔*・菅井径世**.金聲漢*** \\ By Minoru MATSUO, Michiyo SUGAI and Seikan KIM
}

\begin{abstract}
The present paper discusses two main subjects. The first one is concerned with a method for the evaluation of ultimate bearing capacity in which the updated data obtained during the in-situ loading tests are used. The new evaluation method of applying the residual settlements with the total settlement in each loading step is proposed. The other is to show the improved equations of ultimate bearing capacity which are determined based on the statistically analyzed data on many proto-type loading tests done in the fields. The results are compared with the values given by the methods generally used in Japan and the engineering usefulness of the new methods are emphasized.
\end{abstract}

Keywords : bearing capacity, in-situ loading test, nonlinear least square, statistical analysis

\section{1.はじめに}

杭の支持力に関する理論的, 実験的研究は, 古い歴史 と実績を有する. 理論的研究は, 多くの場合, 精緻な支 持力理論の構築に向けられている. その結果, 提案され た支持力式には, 実際には得ることの困難な地盤情報, たとえば詳細かつ高精度の強度定数などを必要とするこ とが多く，実務設計用支持力式としては活用しにくい面 を否定できない. 一方, この方向とは別に, 近年, 現場 載荷試験の重要性が認識され, 実測データが着実に蓄積 されつつある.ただ惜しむらくは, 一般にこれらの載荷 試験データが, 個々の現場での支持力確認の利用にとど まっており，必ずしも普遍的な支持力推定法に向けて系 統的に整理されているとはいいがたい.

本論文では，上記の点を踏まえ，まず載荷試験による 精度の高い極限支持力推定方法を提案した後, 収集した 多数のデー夕の統計的処理に基づく静的支持力式決定法 を提示する. 同時にこれらと, 既往の極限支持力推定法

* 正会員 工博 名古屋大学教授 工学部地盤工学教室 （テ464-01 名古屋市千種区不老町）

** 学生会員 工修 名古屋大学大学院工学研究科地盤工学 専攻 (同上)

*** 正会員 工修（株）日本技術開発・土木本部綜合技術部 （₹160 新宿区大久保 226）
および, 諸官公庁・学協会等における静的支持力式を比 較し, 新しく提案した方法の妥当性を検討する.

\section{2. 載荷試験結果による極限支持力推定法}

\section{（1） 既往の極限支持力推定法}

『クイの鉛直載荷試験基準 1977】 ${ }^{1)}$ では, 荷重～沈下量 曲線が沈下軸に平行とみなされる荷重を極限支持力とし ている. 載荷試験が信頼度の高い支持力推定法であるこ とはいうまでもない, しかし, 現実には, 経済性その他 の理由により, 極限荷重を明確に確認するまで載荷でき る場合は少なく, 上記の基準のみでは極限支持力の定量 的決定が困難の場合が多い.この点に関し, 載荷試験デー 夕に指数関数なよ゙の数学モデルを適用して極限支持力を 評価する方法が提案されている2). 本論文の構成上, そ の中でも一般に用いられている a) Van der Veen ${ }^{3)}$ ，b) 宇都の方法 ${ }^{4) ~ 7)}$ に関して簡単に触れておく必要があるの で以下に結論のみを示す.

a) Van der Veen の方法

荷重〜沈下量曲線は次の指数関数で仮定される.

$P=P_{u}(1.0-\exp (-\alpha S))$.

ここに， $\alpha, P_{u}, P$ および $S$ はそれぞれ定数, 極限支 持力, 荷重および沈下量である. 式（1）を書き直すと, 


$$
S=-\frac{1}{\alpha} \log \left(1.0-\frac{P}{P_{u}}\right)
$$

上式から, 横軸に $\log \left(1-P / P_{u}\right)$, 縦軸に $S$ をとり, い くつか仮定した $P_{u}$ ごとに $P / P_{u}$ と $S$ の関係をプロッ 卜する. 描かれた曲線群のうち最も直線性の高いときの $P_{u}$ が極限支持力值である. この方法は, 極限支持力を 数学モデルで推定する方法として先駆的なものであり, 複雑な数值計算を必要としない利点がある. しかし, 図 の直線性を視覚的に判断するため客観性に乏しいという 問題点がある.

b) 宇都の方法

荷重〜沈下量関係が次のような指数関数で仮定され る.

$$
P=P_{u}\left\{1.0-\exp \left(-\left(\frac{S}{d_{s}}\right)^{m}\right)\right\}+P_{u}^{\prime}
$$

ここに $d_{s}$ は基準変位とよばれ, ほぼ降伏荷重に対応す る沈下量を表わす. $m$ は変位指数とよばれるパラメー ターで $P_{u}^{\prime}$ は原点の補正係数である. 式中のパラメー 夕ー $\left(P_{u}, d_{s}, m, P_{u}^{\prime}\right)$ は, 載荷試験から得られる $P$, $S$ の実測值を用いた非線形回䚻計算より決定され， $\left(P_{u}\right.$ $\left.+P_{u}^{\prime}\right)$ が極限支持力とされる. この方法は, 最近, 最 も注目すべき提案であり, Van der Veen の方法に比べ, 怨意性を排除した点で高く評価される. しかし, 精度の 高い推定には降伏荷重をかなり越えた載荷が必要であ り, また変位指数 $m$ を用いると, 計算が非常に複雑に なり, 演算時間も長くなるという難点は避けられない.

\section{（2）新しい極限支持力推定法の提案}

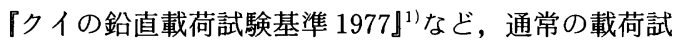
験示様では多サイクル載荷方式を採用している．この方 法によれば各荷重段階で残留沈下量が測定されるから, 沈下量との差として弾性沈下量も求められる. 測定結果 は一般に沈下量曲線, 残留沈下量曲線, 弾性沈下量曲線 として図に表わされるが, 実際に支持力推定に用いられ るのは沈下量曲線だけであり,これはV Van der Veen, 宇都の方法でも同様である. しかし，たとえば杭頭で降 伏の発生を確認したならば，それはとりもなおさず杭先 端地盤での降伏発生を意味しているから, 杭頭の残留沈 下量の挙動は, 杭先端の沈下挙動之密接に関係する. す なわち, 杭の極限支持力推定に残留沈下量曲線を利用す ることはきわめて重要かつ有効である ${ }^{8)}$. さらに, 残留 沈下量を加えれば，それだけデー夕数が増えるため, 統 計学的にも精度向上につながる. 以上の点を踏まえて, 荷重一沈下量曲線亡残留沈下量曲線の 2 つを利用する極 限支持力推定法を以下に提案する ${ }^{9}$.

載荷試験時の荷重〜沈下量関係は, Van der Veen の 方法や宇都の方法に準じ, 指数関数を仮定する.ただし, 式（3）における $m$ は物理的な意味が明確でないので $m=1$ としたうえで, 沈下量 $S$ について整理すると次 式となる.

$$
S=d_{s} \log \left(P_{u} /\left(P_{u}+P_{u}^{\prime}-P\right)\right)
$$

また荷重～弾性沈下量 $\left(S_{\boldsymbol{e}}\right)$ 関係は, 線形で表示する のが妥当だから次式を用いる.

$$
S_{e}=\frac{P-P_{e}^{\prime}}{E^{\prime}}
$$

ここに, $E^{\prime}$ は定数, $P_{e}^{\prime}$ は原点の補正係数である. した がって, 残留沈下量 $S_{r}$ は次式で表わされる.

$$
\begin{aligned}
S_{r} & =S-S_{e} \\
& =d_{S} \log \left(P_{u} /\left(P_{u}+P_{u}^{\prime}-P\right)\right)-\frac{P-P_{e}^{\prime}}{E^{\prime}} .
\end{aligned}
$$

上式の関係から, 次式を最小化するような非線形回帰 計算により, パラメーター $\left(P_{u}, d_{s}, P_{u}^{\prime}, E^{\prime}, P_{e}^{\prime}\right)$ を 決定することができる.

$$
\begin{aligned}
& S_{p}=\sum_{i=1}^{n}\left[S_{i}-\hat{d_{s}} \log \left(\hat{P_{u}} /\left(\hat{P_{u}}+\hat{P_{u}^{\prime}}-P_{i}\right)\right)\right]^{2} \\
& +\sum_{i=1}^{m}\left[\hat{S_{r i}}-\left\{\hat{d_{s}} \log \left(\hat{P_{u}} /\left(\hat{P_{u}}+\hat{P_{u}^{\prime}}-P_{i}\right)\right)\right.\right. \\
& \left.\left.-\frac{P_{t}-\hat{P_{e}^{\prime}}}{\hat{E^{\prime}}}\right\}\right]^{2}
\end{aligned}
$$

このとき, 求めるべき極限支持力は $\left(P_{u}+P_{u}^{\prime}\right)$ で与えら れる.

実際には，パラメーター $\left(P_{u}, d_{s}, P_{u}^{\prime}, E^{\prime}, P_{e}^{\prime}\right)$ は 以下の手順で推定することができる. (1) 実測された荷 重一弾性沈下量関係により, 式 ( 5 )のパラメーター $\left(E^{\prime}\right.$, $\left.P_{e}^{\prime}\right)$ を回帰計算により決定する. (2) (1)で決定した（ $E^{\prime}$, $\left.P_{e}^{\prime}\right)$ と実測の荷重一残留沈下量関係により, 荷重〜沈 下量関係を計算する. (3) (2)で計算した荷重〜沈下量関 係之, 実測の荷重〜沈下量関係の双方を同時に用いて $\left(P_{u}, d_{s}, P_{u}^{\prime}\right)$ を決定する. かくして, 極限支持力 $\left(P_{u}\right.$ $\left.+P_{u}^{\prime}\right)$ が求められるのである.

\section{（3）新しく提案する方法の検討}

前述したように, Van der Veen の方法では $S \sim \log$ $\left(1-P / P_{u}\right)$ の直線性を視覚的に判定しなければならな い欠点があるので, 本節では宇都法との比較において新 提案法を検討する. なお, 宇都法では変位指数 $m$ を $m$ $=1$ とせず $m$ を用いた厳密計算を行っている.ここで 検討に用いたデー夕は, ほぼ極限まで載荷されている 19 例で, すべて打ち込み開端鋼管杭での試験結果であ る.ここでは載荷試験による極限支持力の実測值を真值 とみなし, それとの乘離の大小で精度を検討する. 通常, 極限支持力推定法は, 極限付近までの実測データがない 場合にその有効性が評価されなければならない，そこで ビの程度の載荷レベル（試験荷重／極限支持カ $\times 100$ (\%)) までのデータが得られれば極限支持力をある精

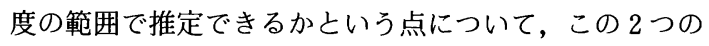




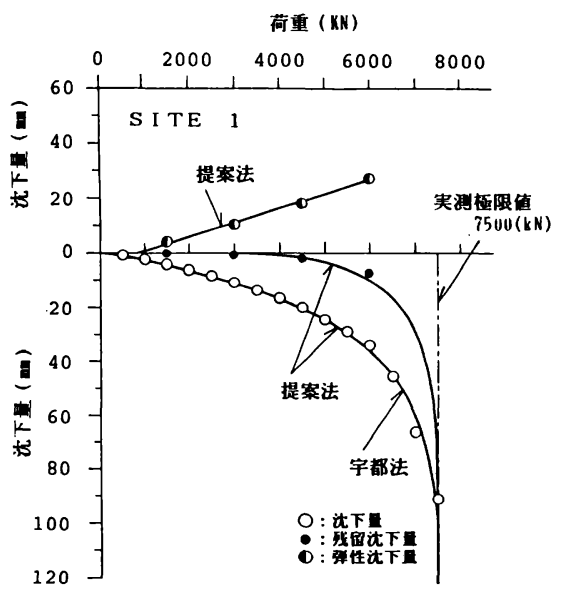

(a) 極限付近までのデータを使用

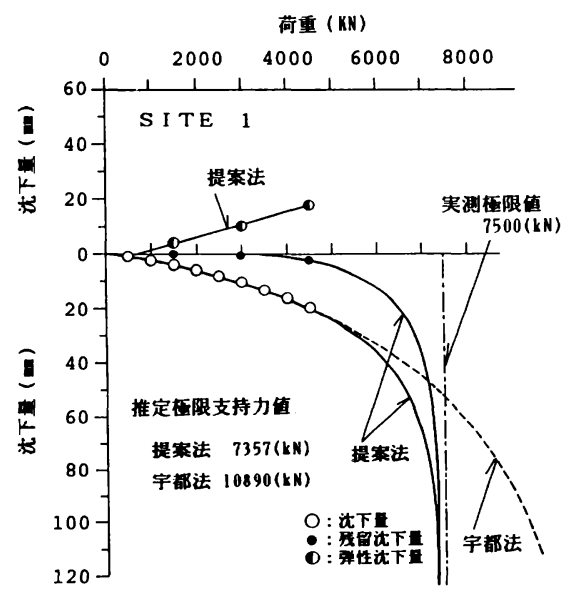

(b) 極限の $60 \%$ 付近までのデータを使用

図一1 推定極限支持力の比較

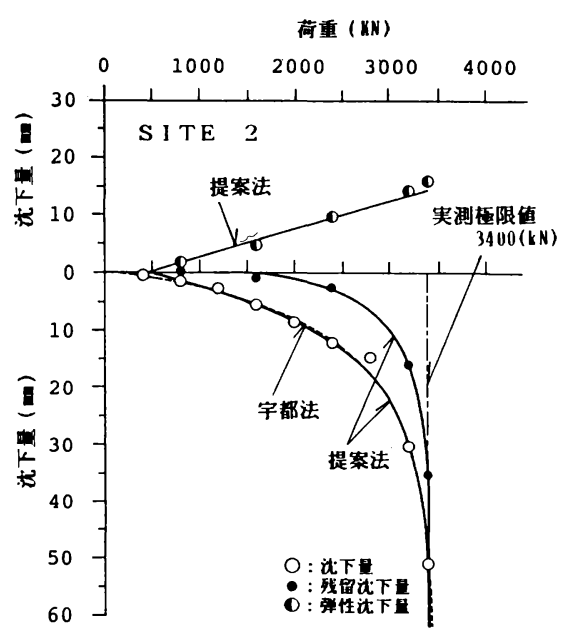

（a）極限付近までのデータを使用

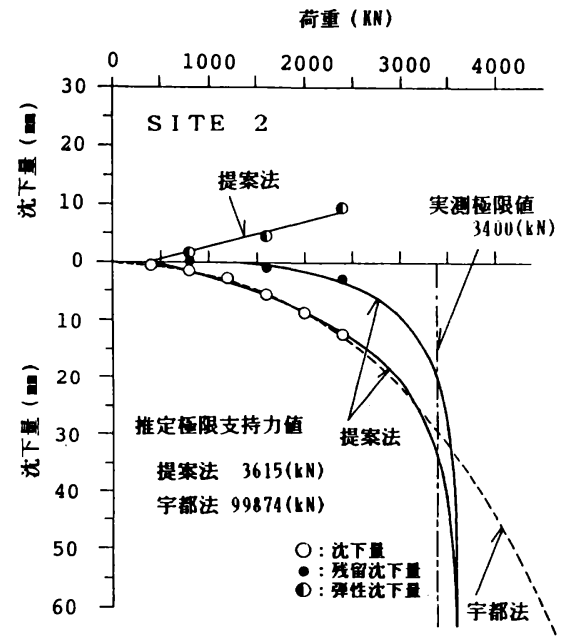

（b）極限の $70 \%$ 付近までのデータを使用

図一2 推定極限支持力の比較

推定法を比較検討した．具体的には載荷荷重を順次 1 段 階ずつ減じてそれまでの試験結果を使って極限支持力を 推定している.

図一1，2 は結果の一例であり, Site 1, 2の 2 地点で の載荷試験結果に関するものである.両図において図(a) は載荷試験の極限值付近までのデータを用いた場合であ り，宇都法，提案法とも実測の荷重～沈下量関係をよく 追跡し，かつ推定極限支持力值にも差はない。一方，図 -1（b)に示す極限值の約 $60 \%$ 載荷レベル，図一2 (b) に示す極限値の約 $70 \%$ 載荷レベルまでのデー夕を使用 した場合をみると，両者の傾向はかなり異なる．すなわ ち, 提案法ではほとんど推定誤差を生じないのに対し, 宇都法では, 外挿する荷重領域の大きい範囲で荷重 沈 下量関係が実測值を大幅に逸脱し，極限支持力にも大き
な推定誤差が生じている．表一1 に検討結果のすべてを

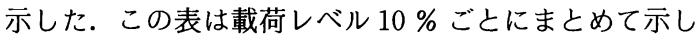
てあるので，その範囲に相当する載荷レベルでの試験が 行われていない場合は欠番となっている. また, 表には, 実測された極限支持力のほかに，載荷レベルごとの実測 値之計算値との差 (=残差: 極限支持力に対する百分率 (\%)）も示してある. 表からわかるように, 提案法の 場合, 載荷レベルが $50 \%$ 前後になると, 推定残差の絶 対値はかなり大きくなるが, それ以上の場合には工学的 に十分精度のよい推定が可能である. 図一3は, 載荷レ ベル別の残差の平均値と標準偏差である. 平均值は各レ ベルとも負の值であり，設計上は全般に安全側である. また, 載荷レベル 40〜60\%の場合を除いて, 残差の平 均值が非常に小さいこと，およびその標準偏差も $20 \%$ 


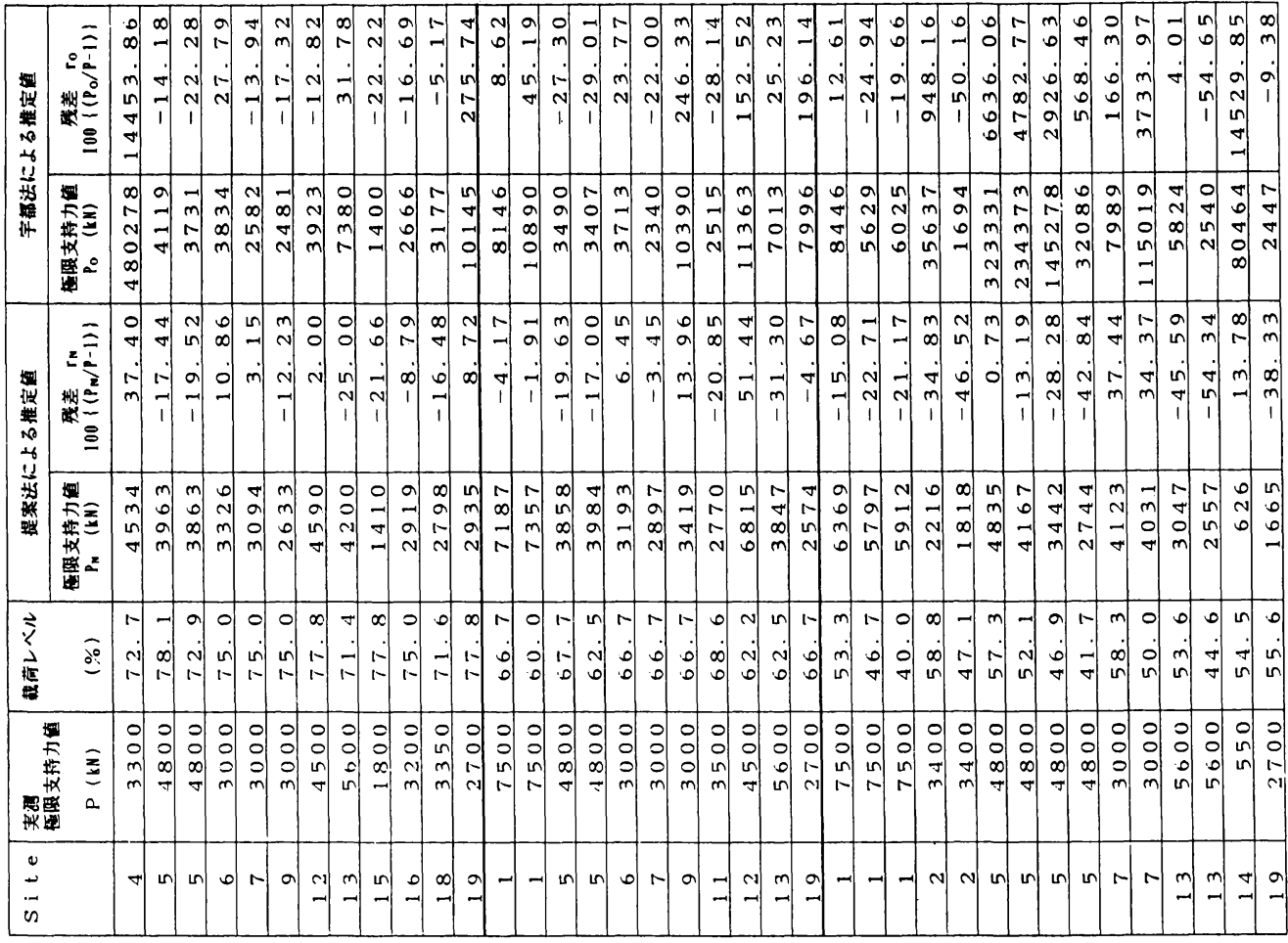

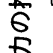

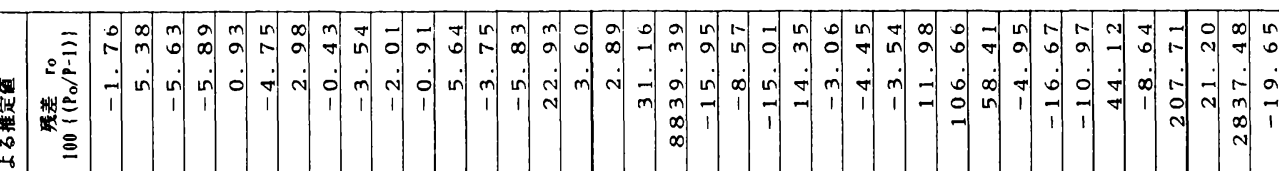

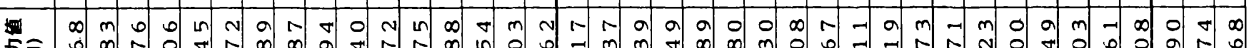

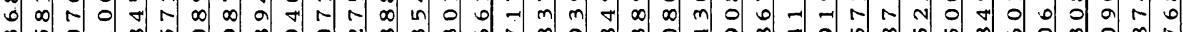

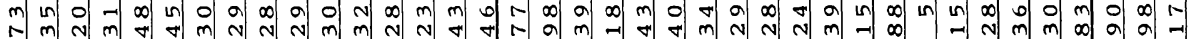
:m.

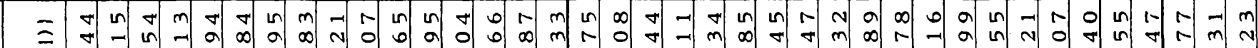

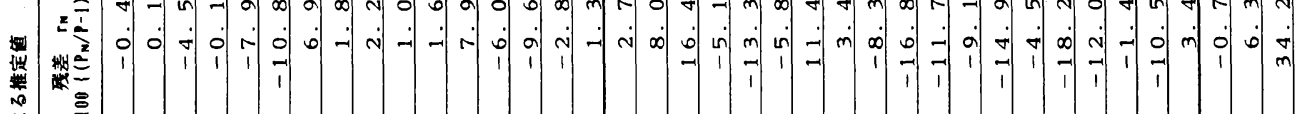

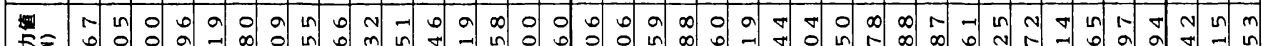
E₹

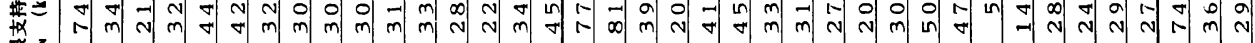
堅

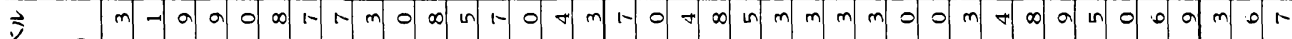

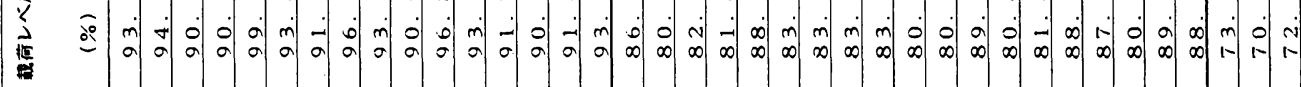

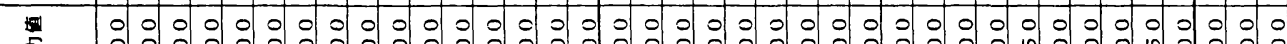
₹

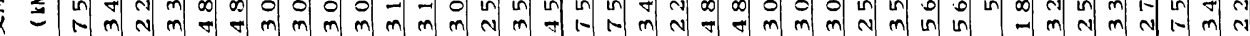

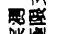




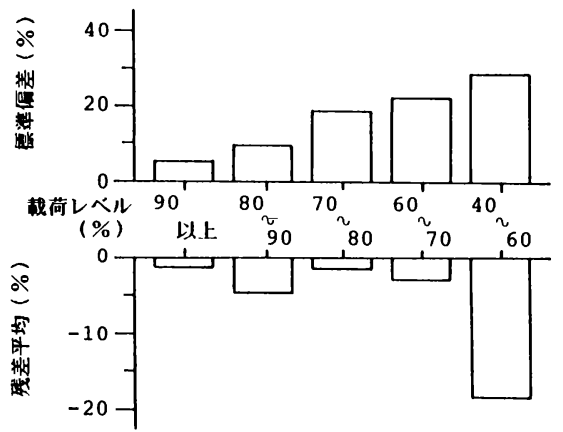

図一3 載荷レベルによる推定極限支持力値の残差の平均値と標
準偏差

以下であることは注目に値する，すなわち，降伏荷重付 近まで載荷するならば，提案法は工学的にみて精度のよ い推定極限支持力值を与えると結論される，なお，表一 1 の宇都法の解析では, 使用実測データを非線形回帰し て求めたパラメーター $\left(P_{u}, d_{s}, m, P_{u}^{\prime}\right)$ を用い推定 した極限支持力值を示しているが，実測值に比へ，総じ て非常に大きな推定值を与えている. 文献 5）によれば, 宇都法の場合，工学的にみてあまりに大きな極限支持力 を推定しそうなときなどには修正が加えられるようであ るが，この修正法が必ずしも客観的一般性を有している ように思えないので修正を加えることができなかった。

\section{3. 統計解析に基づく静的支持力式決定法の 提案}

（1）諸官公庁，学協会の静的支持力式

本節では, 諸官公庁, 学協会の静的支持力式として, 「道路橋示方書 - 同解説 ${ }^{101}$ に準拠する式 (以下道路橋式

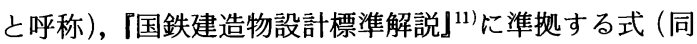
国鉄式)，「建築基礎構造設計指針】 ${ }^{12)}$ に準拠する式（同 建築学会式), 「港湾の施設の技術上の基準・同解説】 ${ }^{13)}$ に準拠する式（同港湾式）を取り上げる.これらを列記 すると以下のようである.

a) 道路橋式

$$
\left.\begin{array}{l}
\begin{array}{l}
(L / D) \leqq 5 \\
P_{u}=6(L / D) \bar{N}_{\rho} A_{\rho}+0.2 \sum N_{s} l_{s} U+1.0 \sum N_{c} l_{c} U \\
(L / D)>5 \\
P_{u}= \\
\end{array} \quad 30 \bar{N}_{\rho} A_{\rho}+0.2 \sum N_{s} l_{s} U+1.0 \sum N_{c} l_{c} U \\
0.2 N_{s} \leqq 10,1.0 N_{c} \leqq 15
\end{array}\right\}
$$

ここに，L, D, $A_{\rho}, U$ は，それぞれ支持層への根入れ 長さ, 杭径, 杭の先端閉塞断面積および杭周長を, $N_{\rho}$, $N_{s}, N_{c}$ は, 支持層, 砂層および粘土層の平均 $N$ 值を, また， $l_{s}, l_{c}$ は，砂層および粘土層の層厚を示す．なお， 以下の各式においても同じ記号はこれらと同内容を示
す.

b) 国 鉄 式

$D<0.8 \mathrm{~m}$

$(L / D) \leqq 5$

$$
P_{u}=5(L / D) \bar{N}_{\rho} A_{p}+0.2 \sum N_{s} l_{s} U+1.0 \sum N_{c} l_{c} U
$$

$(L / D)>5$

$P_{u}=$

$25 \bar{N}_{p} A_{p}+0.2 \sum N_{s} l_{s} U+1.0 \sum N_{c} l_{c} U$

$D \geqq 0.8 \mathrm{~m}$

$(L / D) \leqq 5$

$P_{u}=4\left(L / D^{2}\right) \bar{N}_{p} A_{\rho}+0.2 \sum N_{s} l_{s} U+1.0 \sum N_{c} l_{c} U$

$(L / D)>5$

$$
\left.\begin{array}{r}
P_{u}=\quad 20 / D \bar{N}_{\rho} A_{\rho}+0.2 \sum N_{s} l_{s} U+1.0 \sum N_{c} l_{c} U \\
0.2 N_{s} \leqq 10,1.0 N_{c} \leqq 10
\end{array}\right)
$$

c) 建築学会式

$$
\left.\begin{array}{rl}
P_{u}=30 \eta \bar{N}_{p} A_{p}+(1 / 3) \sum N_{s} l_{s} U+0.5 \sum N_{c} l_{c} U \\
2 \leqq L / D_{1} \leqq 5 & \eta=0.16\left(L / D_{1}\right) \\
L / D_{1}>5 & \eta=0.8
\end{array}\right\}
$$

ここに $D_{1}$ は杭の内径を示している.

d) 港 湾 式

$$
P_{u}=40 \alpha \bar{N}_{p} A_{p}+0.2 \sum N_{s} l_{s} U+\sum c_{a} l_{c} U
$$

ここに $\alpha, c_{a}$ は開端杭の閉塞効果に関する低減率およ び粘土層における土と杭の間の付着力である.

式（8)（11）は，いずれも先端解放の鋼管杭を対象 としたものだが，必ずしも，これらの式が示方書等にこ の形で記されているわけではない，たとえば建築学会式 では, 粘土層の周面摩擦力の算定には, 一般に, 一軸圧 縮強さの $1 / 2$ を用いるべきであるとされている(式 (10) の第 3 項の係数は文献 14）による). また, 以下の解析 で用いた載荷試験杭の直径が，これらの支持力式がその 適用を指定している範囲外の場合もある.このように， 詳細な点には若干問題があるが, 統計的には大きな推定 誤差を生じないことを別に確かめた。 そのうえで，これ らを実用的支持力算定式と考えて，収集したすべての載 荷試験杭に関して上式を適用し，以下の解析を行う。な お, 式 (8) (11) は, いずれも, 第 1 項が杭の先端支 持力, 第 2 項が砂層の周面摩擦力, 第 3 項が粘土層の周 面摩擦力を表わしている.

\section{（2）統計解析に基づく新しい静的支持力式決定法}

式（8)〜(11) は，次式で一般化できる.

$$
P_{u}=a_{1} \bar{N}_{p} A_{p}+a_{2} \sum N_{s} l_{s} U+a_{3} \sum N_{c} l_{c} U
$$

ここに係数 $a_{1}, a_{2}, a_{3}$ の值は, 諸官公庁, 学協会でそ れぞれ独自に与えられている，たとえば，道路橋式では 以下のように決定されている.

杭体の軸力分布が測定されている載荷試験結果から, まず砂層と粘土層の周面摩擦力を算定する. 次に，砂質 
土と粘性土とに分離された周面摩擦力と $N$ 値との関係 が線形的に比例関係で近似される. 式 (8) 中の第 2 項 の係数 0.2 および第 3 項の係数 1.0 はこれらの比例係数 である，以上のように，周面摩擦力に関する係数（本論 文では摩擦係数とよぶ）が特定の限られたデータから決 定される。一般の載荷試験では先端支持力と周面摩擦力 を分離測定することは難しいので, 載荷試験結果として 得られた極限支持力值から, 先の係数を用いた周面摩擦 力の計算值を減じることによって先端支持力值が計算さ れる.この值から杭径や根入れに関係した先端支持力に 関する係数（式 $(8)$ では， $6(L / D)$ および 30$)$ が決 定されるのである.

これからもわかるように, 従来の静的支持力式の決定 は, 式 (12) 中の係数 $a_{1}, a_{2}, a_{3}$ を決定することに帰 着する. 諸官公庁, 学協会の提案式が長年の経験と実績 および論理的考察に基づいていることは論を待たないの であり,これら各式の基本形式を尊重すべきは当然であ る. この観点から, 係数 $a_{1}, a_{2}, a_{3}$ の決定に中心をお いて検討する. 方法論としては, 次式の最小化により係 数を決定する手法を用いる.

$$
\begin{aligned}
S_{\rho} & =\sum_{i=1}^{n}\left(P_{u_{i}}-\hat{P_{u_{i}}}\right)^{2} \\
& =\sum_{i=1}^{n}\left(P_{u_{i}}-\hat{a_{1}} \bar{N}_{p_{i}} A_{p_{i}}-\hat{a_{2}} \sum N_{s_{l}} l_{s_{i}} U_{i}\right.
\end{aligned}
$$

$$
\left.-\hat{a_{3}} \sum N_{c_{i}} l_{c_{i}} U_{i}\right)^{2}
$$

ただし, 式 (12) 中の $a_{1}, a_{2}, a_{3}$ は, 物理的条件とし て以下の条件を満たさねばならない.

$$
\left.\begin{array}{c}
\hat{a_{1}} \geqq 0, \quad \hat{a_{2}} \geqq 0, \quad \hat{a_{3}} \geqq 0 \\
\hat{a_{3}} \geqq \hat{a_{2}}
\end{array}\right\} .
$$

換言すると, 式 (14) の線形不等式の制約条件のもとで, 式（13）に示す非線形な目的関数を最小化する非線形計 画問題に帰着できる.

\section{（3）静的支持力式の分析および検討}

a) 用いた載荷試験データ

種々の解析結果を示す前に, 用いた載荷試験データそ の他準備的事項に触れておく必要がある. 地盤情報とし ては，それ以外の計測值がほとんゼないこともあって， $N$ 值の深さ方向への分布と地層構成図のみである. 図 -4に, 解析に用いた杭の形状を度数分布の形で示す. 杭長としては 10 60 $\mathrm{m}$ の範囲で $30 \mathrm{~m}$ 前後のものが多 く, 杭径は約 $300 \sim 800 \mathrm{~mm}$ の範囲で $600 \mathrm{~mm}$ 前後のも のが多い. また, 支持層への根入れ比（根入れ長さ/杭 径）は2 6 程度のものが多いが, 幅は広い，地表面か ら杭を打止める支持層までに存在する砂層および粘土層 の平均 $N$ 值を杭周面積の分布として示したのが図一5 である．図からわかるようにばらつきは大きいが，砂層 の $N$ 值 $N_{s}$ は $2 \sim 20$ 程度の場合が多い。 また, 粘土層

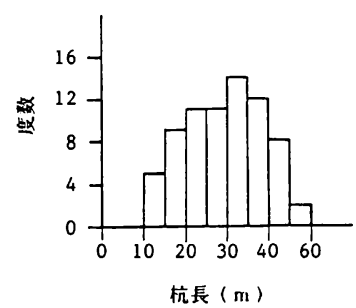

(a) 杭長

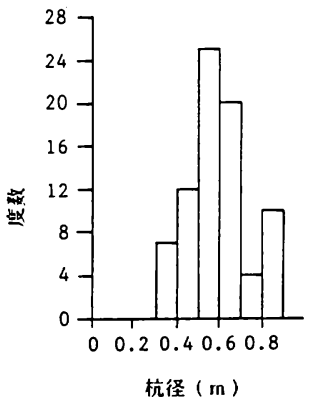

(b) 杭径

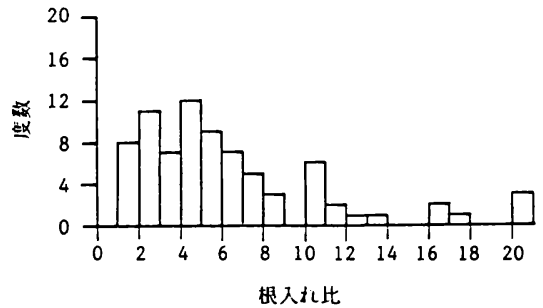

(c) 根入れ比

図一4解析に用いた杭の形状等（デー夕数 78 個）

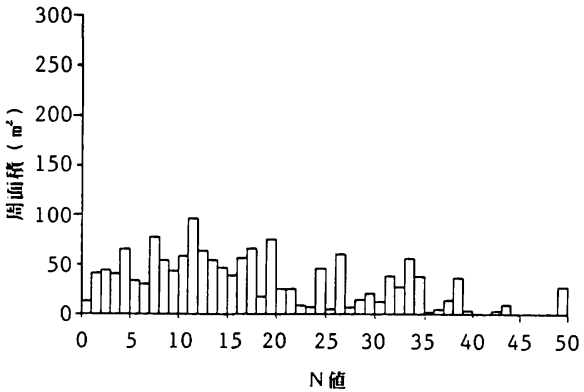

(a) 砂層

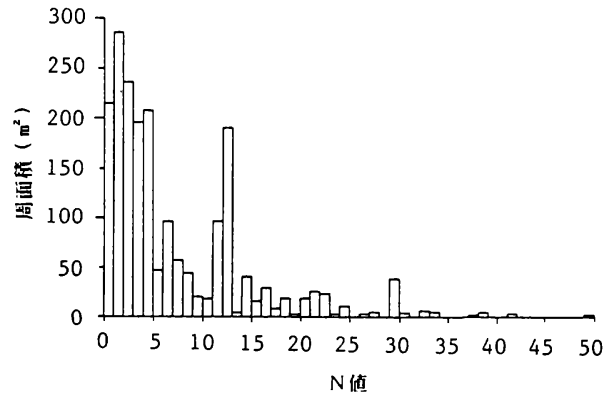

(b) 粘土層

図一5 周面摩擦にかかわる $N$ 值と杭周面積 


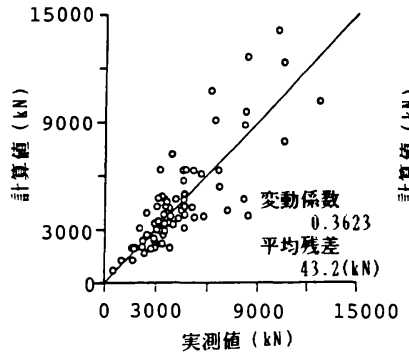

(a) 道路橋式

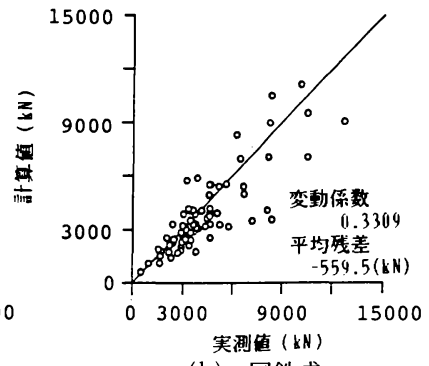

(b) 国鉄式

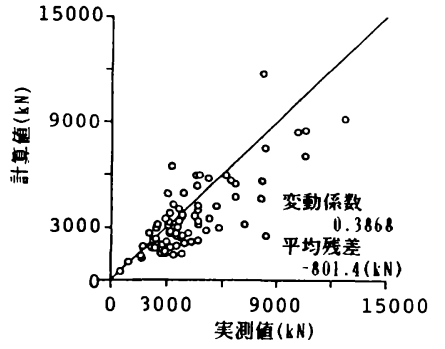

(c) 建築学会式

図一6 実測值と現行支持力式による計算值の比較（デー夕数 78 個）

の $N$ 值である $N_{c}$ は $1 \sim 10$ の範囲のものが多いが, 15 以上の場合もある. 柱状図によると,これらは固結粘土, 固結シルト，土丹などである. なお，ここで杭周面積を 用いたのは以下の理由による. $N$ 值は通常 $30 \mathrm{~cm}$ ごと

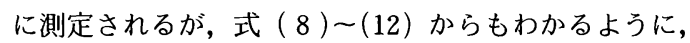
支持力値や $a_{1}, a_{2}, a_{3}$ の決定に影響するのは測定され る $N$ 值の出現回数ではなく,これに杭の周面積を乗じ た値だからである.

b) 現行の支持力式の検討

（1）で代表的な静的支持力式を説明したが, 式（11） の港湾式では先端支持力に関する低減率 $\alpha$ の具体值が 明らかでないので以下の解析の対象から外す. 図一6は, 78 個の全載荷試験データを用いて, 現行式による計算 值と実測値を比較したものである.図からわかるように, いずれの式も比較的よい精度を有しているが，詳細は図 中に併記した残差の平均値 (平均残差) と変動係数をみ てみる必要がある. 道路橋式の平均残差は 3 者のうち最 も小さく, 変動係数値にも現われているように個々の ケースのばらつきはやや大きいが, 平均的には中庸の値 を与える. これに対し, 建築学会式の平均残差は一 $801.4(\mathrm{kN})$ となっており, 図からもわかるように,こ の式は設計上かなり安全側の值を与える. しかし，中小 規模の建物を比較的小さい建築事務所において大きな間 違いを起こさず設計しなければならない建築分野の実情 を勘案すれば，必ずしも不当とはいえない．国鉄式も平 均残差はマイナスで全般に安全側にあるが，変動係数は 0.331 であり,この意味で精度的には国鉄式が最も高く, 道路橋式, 建築学会式の順の結果となった。

c) 提案法による数值計算例

本論文で提案しようとする静的支持力式は地盤情報も 含め, 各種データがよく整った多数の載荷試験結果を統 計的に解析することによって得ようとするものである. 解析および検討は次の項目ごとに, 順を追って進める. すなわち，(1) $N$ 值大の粘土層の周面摩擦に関する係数 の決定法, (2) 根入れ比が先端支持力の係数 $a_{1}$ に与える 影響, (3) 杭径が先端支持力の係数 $a_{1}$ に与える影響, (4)
実務設計に用いるための各係数の有効な桁数についてで ある.

(1) $N$ 值大の粘土層の周面摩擦に関する係数の決定 式（12）の極限支持力は, 先端支持力, 砂層および粘 土層における周面摩擦力の和として 3 つの項で表わされ る. ところで，図一5に示したように，粘土層にも $N$ 值が 15 を越えるような, 過圧密度が非常に高いと考え られる層がある. 式（8)，（9）にみられるように，現 行式においても周面摩擦に関する粘土層の $N$ 值には, 式中に示すような適用限界を設けているが, これは妥当 である.すなわち，このような粘土では， $N$ 值の小さ な正規圧密粘土層や若干過圧密された層とは力学特性, 特にせん断特性が非常に異なるから, 当然, 摩擦係数も 同一規範では扱えないと考えるのが正当である. 本研究 では粘土層の種頑をある值の $N$ 値 $\left(N_{L}\right)$ によって $2 つ$ に区分けし，それぞれに，別の係数を用いることとする. 式で表わすと以下のようである.

$$
\begin{gathered}
P_{u}=a_{1} \bar{N}_{\rho} A_{\rho}+a_{2} \sum N_{s} l_{s} U+a_{3}^{\prime} \sum N_{c}^{\prime} l_{c} U \\
+a_{3}^{\prime \prime} \sum N_{c}^{\prime \prime} l_{c} U \\
\quad\left(N_{c}^{\prime} \leqq N_{L}, N_{c}^{\prime \prime}>N_{L}\right)
\end{gathered}
$$

ここに $a_{3}^{\prime}, a_{3}^{\prime \prime}$ は，それぞれ、 $N_{L}$ 以下の平均 $N$ 値を示 す粘土層，および $N_{L}$ より大きな平均 $N$ 值を示す粘土 層に関する周面摩擦力の係数である. $N_{L}$ の值は, 粘土 の力学に関するこれまでの経験に基づけば 10 前後と考 えられる。しかし， $N$ 值自身が室内土質試験のような 精度を有しないことを考慮して, ここでは $N_{L}$ を 1 から 50 まで変えて支持力值計算を行い, それぞれに対して 決定された係数による式の精度を検討する手法を取る. 図一7 はその結果である.この図は, 各 $N_{L}$ 值で粘土層

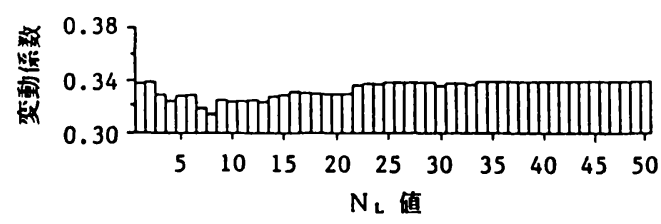

図一7 粘土属分類のための $N_{L}$ と式の精度 
表一2 係数 $a_{1}, a_{2}, a_{3}^{\prime}, a_{3}^{\prime \prime}$ の計算結果

\begin{tabular}{|c|c|c|c|c|c|}
\hline 10 & & & 㑧娄 & 数 & \\
\hline 30. & 0 & 1.172 & 0.381 & 97 & \\
\hline
\end{tabular}

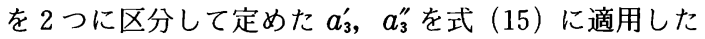
支持力值を実测值と比較して求めたものである.図から， $N_{L}=8$ の変動係数が最小, 換言すると静的支持力式の精 度が最もよくなる.したがって， $N_{L}$ として 8 を採用す ることにするが, これは粘土の力学の経験に照らして妥 当である.

表一 2 に, $N_{L}=8$ とした場合の係数 $a_{1}, a_{2}, a_{3}^{\prime}, a_{3}^{\prime \prime}$ の值亡支持力值に関する変動係数を示す. 表で注目すべ きは, 非線形計画問題として定式化した提案法により算 定した各係数が，現行の各静的支持力式に採用されてい る值と大差ないことである．ただし， $a_{1}$ は根入れ比や 杭径に大きく影響されると考えられるので, 表一2に基 づき $a_{2}, a_{3}^{\prime}, a_{3}^{\prime \prime}$ をそれぞれ，0.15，1.17，0.38に固定

\section{表一3 根入れ比別の $a_{1}$ の計算結果}

\begin{tabular}{|c|c|c|}
\hline 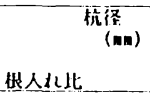 & 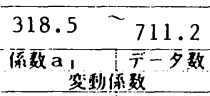 & 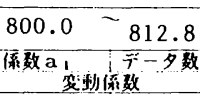 \\
\hline$\sim$ & $-\quad 0$ & $-\quad 00$ \\
\hline $1.0-$ & $\begin{array}{r}31.87 \quad 7 \\
0.1267\end{array}$ & $10.50 \quad 1$ \\
\hline $\begin{array}{r}2.0- \\
3.0 \\
\end{array}$ & $\begin{array}{c}15.617^{8} \\
0.3117^{8}\end{array}$ & $\begin{array}{r}10.49 \quad 3 \\
0.3268 \\
\end{array}$ \\
\hline $3.0 \sim 4.0$ & $\begin{array}{r}24.29 \quad 5 \\
0.0667\end{array}$ & $\begin{array}{c}33.09 \quad 2 \\
0.2087\end{array}$ \\
\hline $\begin{array}{r}4.0 \sim \\
5.0\end{array}$ & $\begin{array}{c}33.21 \quad 12 \\
0.2587\end{array}$ & $\begin{array}{lll}- & 0\end{array}$ \\
\hline $\begin{array}{r}5.0-6.0 \\
\end{array}$ & $\begin{array}{c}38.06 \quad 7 \\
0.1816 \\
\end{array}$ & $\begin{array}{c}44.67{ }^{2} \\
0.1862 \\
\end{array}$ \\
\hline $\begin{array}{r}6.0 \sim \\
7.0 \\
\end{array}$ & \begin{tabular}{c|r}
34.09 & 7 \\
0.2761
\end{tabular} & $-\ldots$ \\
\hline $\begin{array}{r}7.0 \sim \\
8.0 \\
\end{array}$ & $\begin{array}{c}43.62 \quad 4 \\
0.1202 \\
\end{array}$ & $\begin{array}{r}25.99 \\
-\end{array}$ \\
\hline $\begin{array}{r}8.0 \sim \\
9.0 \\
\end{array}$ & $\begin{array}{c}92.18 \quad 2 \\
0.1619 \\
\end{array}$ & $\begin{array}{r}35.93 \\
-\end{array}$ \\
\hline $9.0 \sim$ & $-\ldots$ & $-\ldots$ \\
\hline 10.0 & $\begin{array}{c}32.03 \quad 16 \\
0.2871\end{array}$ & $\begin{array}{ll}-\quad & 0 \\
- & \end{array}$ \\
\hline
\end{tabular}

したうえで， $a_{1}$ についての検討をさらに深める.

(2) 根入れ比が先端支持力の係数 $a_{1}$ に与える影響

表一3 は, 載荷試験杭をその杭径 $800 \mathrm{~mm}$ で区分し, 根入れ比別にまとめたデー夕から計算された $a_{1}$ の值, 支持力値に関する変動係数, デー夕数を示している. $800 \mathrm{~mm}$ 以上の径をもつ杭を別にした理由は，この種の 大口径の杭の先端支持力は一般に閉塞効果の影響が大き く, 諸官公庁や学協会の静的支持力式においても対象外, あるいは別の式（国鉄式の場合）を設けているためであ る.

表にみられるように，一般に根入れ比が小さいときに は $a_{1}$ 值は小さい. ただし, 杭径 $711.2 \mathrm{~mm}$ 以下で, 根 入れ比が 2 以下の場合にだけ特別に大きな值を示してい る.これは, 施工に際し, 支持層に深く根入れをするま でに先端地盤が十分な抵抗を示したため打止められたも のと推測されるが, 理由を記した正確な記録はない. 現 行各式の適用においても, この種の杭は十分根入れされ た場合とみなして計算しなおすと（たとえば道路橋式の 場合， $a_{1}$ として $6(L / D)$ ではなく 30 を用いる), 各式 の精度は，表一4のように，図一6 と比較してわずかな がらよくなる. 以上の結果から，係数 $a_{1}$ に関しては, 根入れ比 2 以下の場合, $2 \sim 3,3 \sim 4,4$ 以上の 4 つの範 囲に分けて別個に求めるのがよいと考えられる．結果は 次の検討に含めて示す.

(3) 杭径が先端支持力の係数 $a_{1}$ に与える影響

表一5 は，根入れ比で 4 つに区分し，さらに各杭径別 に求めた $a_{1}$ の值, 支持力值に関する変動係数, デー夕 数を示している. なお, 杭径 $800 \mathrm{~mm}$ 以上の大口径杭に 関しても一応の計算を行っているが, 前述の閉塞効果の 問題があることに加え, 載荷試験データが現時点ではき わめて少ないので, ここに提案する式の適用限界は $711.2 \mathrm{~mm}$ までのものとしたい. したがって, 以下の解 析は杭径 $711.2 \mathrm{~mm}$ 以下のデー夕のみを用いて行う. た

\section{表一4 根入れ比 2 以下の先端支持力の係数を変更した場合}

\begin{tabular}{|c|c|c|c|}
\hline & 道 路槄式 & 国 铁 & 保等会式 \\
\hline 策 & 0.3615 & 0.3259 & 0.3858 \\
\hline
\end{tabular}

表一5 杭径別の $a_{1}$ の計算結果

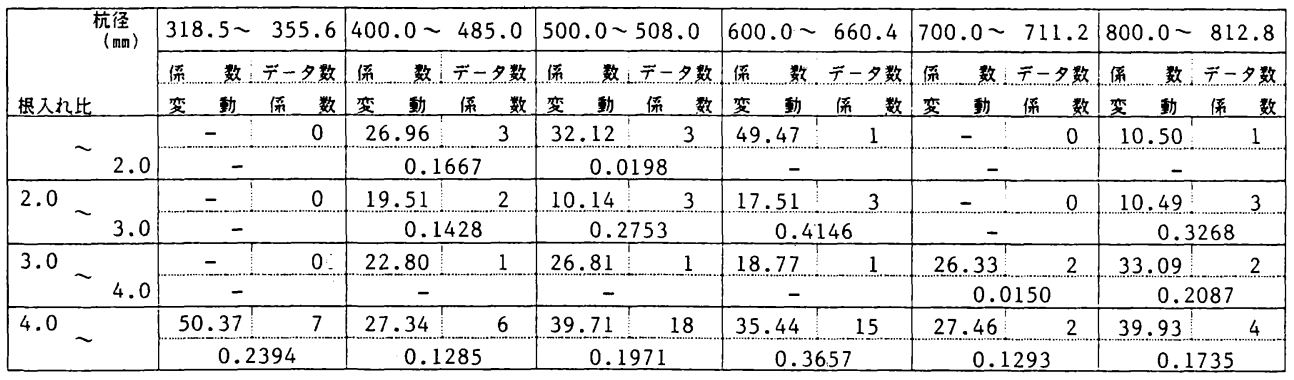


表一 6 杭径 $711.2 \mathrm{~mm}$ 以下のデータによる再計算

\begin{tabular}{|c|c|c|c|c|}
\hline $\mathrm{N}_{L}$ & 你 & 俑数 $a_{3}$. & 倮知 $\mathbf{a}_{3}$ & $\vec{r}$-夕数 \\
\hline 8 & 0.148 & 1.184 & 0.382 & 68 \\
\hline
\end{tabular}

\section{表一7 根入れ比別の $a_{1}$ の計算結果}

\begin{tabular}{|c|c|c|c|c|}
\hline \multirow{2}{*}{\multicolumn{2}{|c|}{ 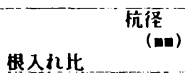 }} & \multicolumn{2}{|c|}{318.5} & 711.2 \\
\hline & & 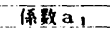 & 变動原㽬 & $\overline{\bar{r}}=$ 多致 \\
\hline & 2.0 & 31.81 & 0.1265 & 7 \\
\hline 2.0 & 3.0 & 15.55 & 0.3115 & 8 \\
\hline 3.0 & 4.0 & 24.18 & 0.0657 & 5 \\
\hline 4.0 & & 34.94 & 0.2952 & 48 \\
\hline
\end{tabular}

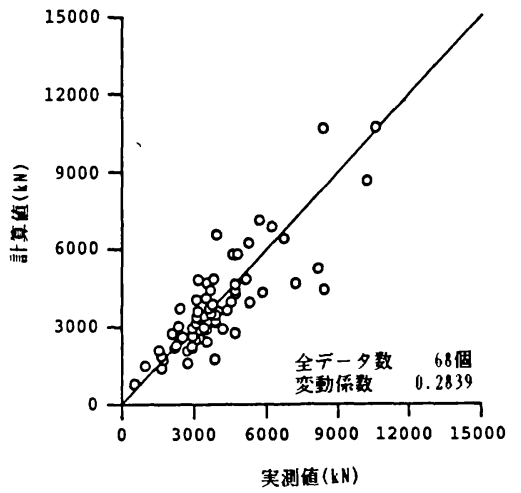

図一8 実測詙と提案法による計算値の比較

だし，この場合でも，これまでの $N_{L}, a_{2}, a_{3}^{\prime}, a_{3}^{\prime \prime}$ の計 算結果は，表一 6 に示すとおりであり，ほとんど変わら ない. 以下, $N_{L}, a_{2}, a_{3}^{\prime}, a_{3}^{\prime \prime}$ の值をそれぞれ, 0.15, 1.18, 0.38 として解析をすすめる. また, 表一5の結果によれ ば，杭径 $300 \mathrm{~mm}$ クラスのものは閉塞効果が十分に発揮 されるものと考えられ，比較的大きな係数值を示してい るが,やはりデー夕数の少ないことおよび小口径杭の取 り扱いが通常は若干粗雑になる実務上の安全性を考慮し て，他の杭と同じ係数を用いることにする.

(4) 実務設計に用いるための各係数の有効な杕数

表一7 は, 以上のような区分けをして求めた $a_{1}$ 值之 そのときの変動係数, デー夕数を示したものである.さ らに，図-8 はこれらの值を式（15）に適用して求めた 計算値と載荷試験における実測値を比較したものであ る. 当然のこととはいえ, 提案法では, 図一6に示した いずれの支持力式よりも高い精度の推定值を与えてい る.なお，実用式として用いる場合には，工学的に有効 な精度を保持しつつ，各係数值はできるだけ簡単な方が よい.この観点から表一7の值を再整理したものが表一 8 である. 式の精度は, 同じく表中の変動係数 (0.285) によって示したように図一8と比較してほとんど落ち ず，実用的にはこれで十分である．新しく提案する実用 式を以下に示す.
表一8 実用式の係数值

\begin{tabular}{|c|c|c|c|c|}
\hline 良人圲比 & 保数的， & \multicolumn{2}{|c|}{ 根入几比 } & 俰数a \\
\hline-2.0 & 32.0 & 3.0 & -4.0 & 24.0 \\
\hline $2.0-3.0$ & 16.0 & 4.0 & - & 35.0 \\
\hline $\begin{array}{r}\text { 係数 } \mathbf{a}_{2} \\
0.15 \\
\end{array}$ & \multicolumn{2}{|c|}{$\begin{array}{r}\text { 俰数 } \mathbf{a}_{3} \\
1.20 \\
\end{array}$} & \multicolumn{2}{|c|}{$\begin{array}{r}\text { 係数 } \mathrm{a}_{3}{ }^{\prime} \\
0.40 \\
\end{array}$} \\
\hline 変動伱数 & \multicolumn{2}{|c|}{0.2847} & $\overrightarrow{\boldsymbol{r}}-g$ & 68 \\
\hline
\end{tabular}

$$
\begin{aligned}
& D \leqq 711.2 \mathrm{~mm} \\
& P_{u}=a_{1} \overline{N_{p}} A_{p}+0.15 \sum N_{s} l_{s} U+1.20 \sum N_{c}^{\prime} l_{c} U \\
& +0.40 \sum N_{c}^{\prime \prime} l_{c} U \\
& L / D \leqq 2 \quad a_{1}=32 \quad \text { (打止め時に十分 } \\
& \text { な先端支持力が } \\
& 2<L / D \leqq 3 \quad a_{1}=16 \\
& 3<L / D \leqq 4 \quad a_{1}=24 \\
& L / D>4 \quad a_{1}=35 \\
& \left(N_{c}^{\prime} \leqq 8, \quad N_{c}^{\prime \prime}>8\right)
\end{aligned}
$$

\section{4. おわりに}

本論文は, 載荷試験結果に基づく極限支持力推定法之 統計解析に基づいた静的支持力式決定法とを提案したも のである．主な結果は，以下のとおりである。

（1）既往の極限支持力推定法の検討をもとに，杭頭 での荷重〜沈下量に加え, 残留沈下量データをも利用し た新しい，精度の高い支持力推定法を提案した。

（2）先端支持力之周面摩擦が分離されていない数多 くの載荷試験結果を統計的に解析することによって, そ の分離を可能とするような新しい静的支持力式決定法を 提示し，その工学的有用性を従来法との精度の比較に よって確かめた.

なお，実務設計を行う場合は，まず載荷試験実施の有 用性の検討，次いで実施する場合には載荷試験の規模や 載荷レベルの検討が必要である.これらは設計の対象之 なる構造物の重要性之密接に関係するが，その評価法お よび決定法に関しては別の論文で報告したい。

本研究の遂行にあたり, 徳島大学助教授 鈴木 壽博 士に有益なご助言とご助力を，また載荷試験データの収 集に関し, 名城大学教授 堀内孝英博士および川崎製鉄 株式会社の関係各位に多大のご協力を頂きました.ここ に付記し，深甚の謝意を表わします.

\section{参 考 文 献}

1）土質工学会編：クイの鉛直載荷試験基準・同解説，1977.

2）土質工学会編：杭基礎の設計法とその解説, 1985.

3) Van der Veen, C. : The Bearing Capacity of a Pile, Proc. 3 rd ICSMFE, Vol.2, pp. 84 90, 1953.

4) 宇都一馬・冬木 衛·近藤 博・桜井 学：クイの載荷 
試験結果の一整理法, 第 13 回土質工学研究発表会講演集, pp. 813 816, 1978.

5) 浅沼秀弥・宇都一馬 - 冬木 衛 - 桜井 学: 杭の $P \sim S$ 曲線のパターン分類について, 第 17 回土質工学研究発表 会講演集, pp. 2085 2088, 1982.

6) 宇都一馬 - 冬木 衛 - 桜井 学: 指数関数係の回帰式に ついて, 第 18 回土質工学研究発表会講演集, pp. 935 936, 1983.

7) 宇都一馬・冬木 衛・桜井 学: 載荷試験から得られる 荷重～変位曲線の非線形回帰計算について (その 3$)$, 土 木学会第 38 回年次学術講演会講演概要集, 第 III 部門, pp. $607 \sim 608,1983$.

8）吉成元伸：載荷試験から支持力を推定するうえでの問題 点, 土と基礎, Vol.23-7, pp. 27 33, 1975.

9）松尾 稔・鈴木 壽・金 聲漢：荷重～沈下量曲線と残
留沈下量曲線を用いた極限支持力推定法の提案, 第 22 回 土質工学研究発表会講演集, pp. 1165 1166, 1987.

10）日本道路協会：道路橋示方書・同解説, IV下部構造編, 1987. 5.

11）土木学会編: 国鉄建造物設計標準解説（基礎構造物, 抗 土圧構造物), 1986 .

12）日本建築学会：建築基礎構造設計指針，1988 年 1 月.

13）日本港湾協会：港湾の施設の技術上の基準 - 同解説, 1979.

14）土質工学会編：構造物基礎の設計計算演習, pp. 111 139, 1982.

15）松尾 稔・鈴木 壽・菅井径世：統計解析に基づいた静 的支持力式決定法の提案, 土木学会第 42 回年次学術講演 会講演概要集, 第吕部門, pp. 708 709, 1987.

(1988.11.14 • 受付) 